\title{
WATER SUPPLY SPRING ZONE NOVLJANSKA ŽRNOVNICA (CROATIA) - NEW QUANTITIES OF DRINKING WATER IN THE CONDITIONS OF SALT WATER INTRUSION
}

\author{
IZVIRNO OBMOČJE NOVLJANSKA ŽRNOVNICA (HRVAŠKA) \\ ZA VODOOSKRBO - NOVE KOLIČINE PITNE VODE \\ V RAZMERAH VDORA SLANE VODE
}

\author{
Ranko BIONDIĆ ${ }^{*}$, Božidar BIONDIĆ ${ }^{1} \&$ Hrvoje MEAŠKI ${ }^{1}$
}

\begin{abstract}
UDC 556.332.7:551.44(497.5)

Ranko Biondić, Božidar Biondić \& Hrvoje Meaški: Water supply spring zone Novljanska Žrnovnica (Croatia) - new quantities of drinking water in the conditions of salt water intrusion

This paper presents an approach for solving the problem of exploitation of freshwater in the coastal karst aquifer during summer dry periods in the conditions of potential salt water intrusion. The approach is presented on the example of spring zone Novljanska Žrnovnica, situated in the northern part of Croatian Adriatic coastal region. The spring zone is used for water supply (about $250 \mathrm{l} / \mathrm{s}$ ) of an important tourist area of Crikvenica and Novi Vinodolski. After unsuccessful attempts of physical separation of freshwater system from the sea influence, by construction of grout curtain, hydrogeological studies have focused on the possibility of groundwater capturing in the hinterland of discharge zone, outside of the zone of periodical salinity. The final research results with the exploitation well in the spring hinterland can serve as a model for research and exploitation of drinking water in natural conditions of unstable freshwater-saltwater interface in similar natural conditions. Keywords: freshwater-saltwater interface, coastal karst aquifers, hydrogeological research, exploitation well, karst spring Novljanska Žrnovnica, Croatia.
\end{abstract}

Izvleček UDK 556.332.7:551.44(497.5)

Ranko Biondić, Božidar Biondić \& Hrvoje Meaški: Izvirno območje Novljanska Žrnovnica (Hrvaška) za vodooskrbo nove količine pitne vode $v$ razmerah vdora slane vode

Članek predstavlja pristop $\mathrm{k}$ reševanju težave $\mathrm{z}$ izrabljanjem sladke vode $\mathrm{v}$ obalnem kraškem vodonosniku med poletnim sušnim obdobjem, ko prihaja do možnosti vdora slane vode v vodonosnik. Pristop je predstavljen na primeru izvirnega območje Novljanska Žrnovnica, ki se nahaja v severnem delu hrvaške jadranske primorske regije. Izvirno območje je zajeto za vodooskrbo (okoli 250 l/s) pomembnega turističnega območja Crikvenice in Novega Vinodolska. Po neuspešnih poskusih fizične ločitve sistema sladke vode od vpliva morja in po izgradnji injekcijske zavese so se hidrogeološke študije osredotočile na možnosti zajetja podzemne vode $\mathrm{v}$ zaledju območja praznjenja in izven območja občasnega zaslanjevanja. Končni raziskovalni rezultati s pomočjo raziskovalne vrtine v zaledju izvira lahko služijo za model raziskovanja in izrabe pitne vode $\mathrm{v}$ naravnih razmerah nestabilne meje med sladko in slano vodo $v$ podobnih naravnih razmerah.

Ključne besede: meja med sladko in slano vodo, obalni kraški vodonosniki, hidrogeološke raziskave, raziskovalna vrtina, kraški izvir Novljanska Žrnovnica, Hrvaška.

\section{INTRODUCTION}

Croatia is a country with more than a thousand islands and with thousands of kilometres of coastline along the east side of the Adriatic Sea. The coastline is a great advantage for tourism development, but tourism development also increases drinking water demand. At the same time, water supply is largely organized by capturing of coastal karst springs. Due to its specific structure and openness toward the sea, coastal aquifers are in condition of unstable balance of freshwater-saltwater interface during summer dry

\footnotetext{
${ }^{1}$ University of Zagreb, Faculty of Geotechnical Engineering, Hallerova aleja 7, HR-42000, Varaždin, Croatia, e-mail: rbiondic@gfv.hr Received/Prejeto: 1.2 .2012
} 
periods, which results with periodical sea water intrusions.

The coastal zone is very indented and various in geomorphologic forms, from relatively flattened parts in the north-western coastal area up to steep rocky coastline, especially expressed in the region of Dalmatia. Coastal area is mainly built of high permeable carbonate rocks, which puts the inland freshwater systems under the direct influence of the sea (Fig. 1). Certain areas are built of impermeable clastic sediments (flysch), and in these areas, the impact of salinity is much lower.

drinking waters are maximal, and some important tourist areas do not have stable sources of drinking water during summer dry periods. One of such area is the Crikveničkonovljanska Riviera, which have a permanent population of about 16,000 inhabitants. This area has an important role in the development of tourism in the north Adriatic region, and the total number of residents in summer rises to over than 50,000. The Riviera has a common water supply system, related to the exploitation of fresh water from the coastal spring zone Novljanska Žrnovnica, whose yield ranges between 0.5 and $7.5 \mathrm{~m}^{3} / \mathrm{s}$.

The spring zone Novljanska Žrnovnica is located in a deep cove, south of Novi Vinodolski, on the coast, in a typical karst rocky area with the possibility of direct contact of freshwater and the sea (Fig. 2).

The first indications of salinity of the spring zone during summer dry periods were observed in the middle of the last century after a significant increase in exploitable quantities for then growing tourism (Biondić, B. \& Šaban 1973). At that time it was very fashionable to solve such problems by "physical" separation of freshwater from the sea by construction of grout curtains (Pavlin 1973), but relatively little knowledge of the geology and the genesis of karst system had then resulted in the construction of mainly too shallow grouting curtains with limited hydrogeological function. Situation with salinity of the spring zone was then currently improved, but

The coastal area and islands are relatively sparsely populated, with a concentration of population only in larger towns. Islands are much less populated than the rest of the coastal area. Generally, in Croatian coastal area, there are around 1.5 mil inhabitants permanently residing, but during summer seasons, the population are doubled because of tourism, which creates major problems in the organization of the life in entire municipal area. In particular, it relates to water supply, because at the time of minimal fresh water discharge from karst catchments needs for with further increase of extraction rates, all problems of unstable relationship between saltwater and freshwater have been renewed.

The occurrences of salinity of the spring zone in the early nineties of the last century were the reason for starting a new research programmes with a focus on testing the functioning of the existing grouting curtain and planning of new technical operations at the spring zone in order to improve the existing situation. In the first stage, all data from previous researches and con- 
struction of grouting curtain was analysed in detail. Also a detailed hydrogeological map of wider source zone has been done, and after that drilling of two deep exploration wells in the area of previously constructed grouting

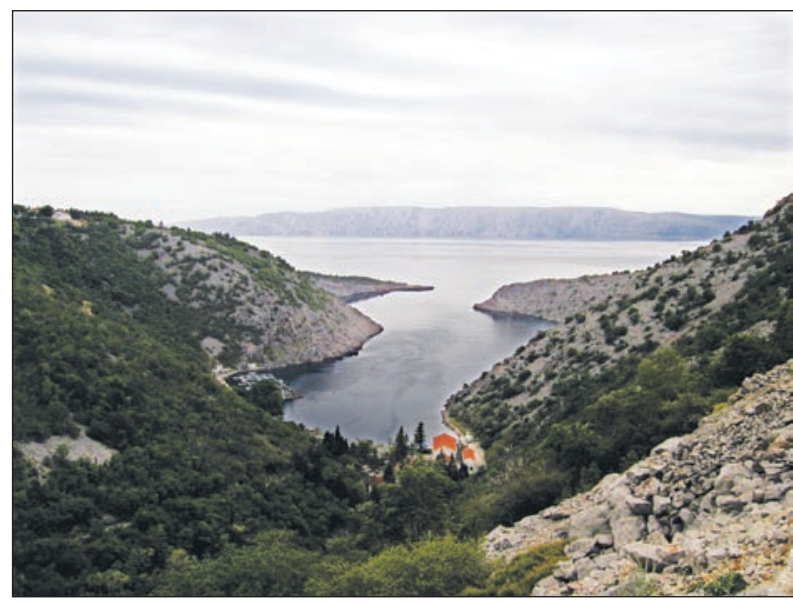

Fig. 2: Coastal spring zone Novljanska Žrnovnica (Photo: R. Biondić).

curtain, hydrogeochemical analyses of the spring zone Novljanska Žrnovnica, hydrological measurement and analysis, pumping tests of vulnerable parts of the spring zone Novljanska Žrnovnica in extreme dry conditions, etc. All those investigations were done with the ensuring the normal functioning of the water supply system (Biondić, R. et al. 1999; Biondić, R. 2004).

In the second stage a detailed geophysical investigations and drilling of exploration wells in zones of groundwater inflow to the spring zone have been done, together with detailed hydrochemical measurements at springs and wells, measurements and processing of hydrologic data, tracing tests of groundwater flows and processing of all hydrogeological data with the proposals of capturing fresh water outside of salinity zone (Biondić, B. et al. 2007a).

The third stage was focused on the detailed hydrogeological investigations of periodical spring Sušica, situated in hinterland of the captured springs. The aim was to determine the location of the future exploitation well for the condition of extreme dry periods (Biondić, B. et al. 2009), which was successfully constructed in 2010. It is situated near the periodical spring Sušica, and its total depth is $80 \mathrm{~m}$ (Biondić, B. \& Biondić, R. 2010). The results are presented in this paper as possible conceptual model for research and exploitation of drinking water in unstable natural relationships of freshwater and sea in coastal karst areas.

\section{HYDROGEOLOGICAL DESCRIPTION}

The catchment area of the spring zone Novljanska Žrnovnica is built of carbonate and clastic rocks from the Upper Triassic to Paleogene age and of the Quaternary deposits (Šušnjar et al. 1970; Grimani et al. 1963). Water permeability of carbonate rocks varies depending on the participation component of dolomite in composition, whereas the clastic rocks in general are impermeable and represent barrier for the movement of groundwater through permeable carbonate medium. Permeability of Quaternary sediments varies, depending on lithological composition. These sediments because of limited thickness may affect the type of infiltration of precipitation, but generally, they do not have influence on events in the saturated parts of the carbonate aquifer. Regional groundwater flow tracing tests (Biondić, B. \& Goatti 1973 , 1975) have shown that a catchment size is over $1,000 \mathrm{~km}^{2}$ (Biondić, B. et al. 1996). The catchment occupies an area from Gorski Kotar region in the northwest to the southeast Lika region (Fig. 3).

Fig. 3 shows nearly $100 \mathrm{~km}$ broad discharge zone along the coastal area. In this area, the spring zone Nov- ljanska Žrnovnica is just one of the bays, but the bay with the largest concentration of water discharge from the catchment area. This spring zone has much better hydrologic characteristics than the other coastal spring zones, and is only successfully captured for public water supplying. However, occasional salinity problems occur, especially in conditions of increased pumping rates during extreme summer dry periods. Reasons are karstification of carbonate rocks to depths greater than $140 \mathrm{~m}$ below present sea level as a consequence of changes in sea levels during the Quaternary (Šegota 1968). By sea level rise after the last glaciation, specifically heavier seawater came into direct contact with coastal freshwater systems filling the deep parts of the karst underground. In this way, the fresh water system are pushed deeper into the coastal area during summer dry periods, and parts of spring zone (submarine and coastal springs) are sunk with sea, which enables recharge of deeper karst aquifer with saltwater.

Geological settings of the spring zone Novljanska Žrnovnica is rather simple, because the location is 


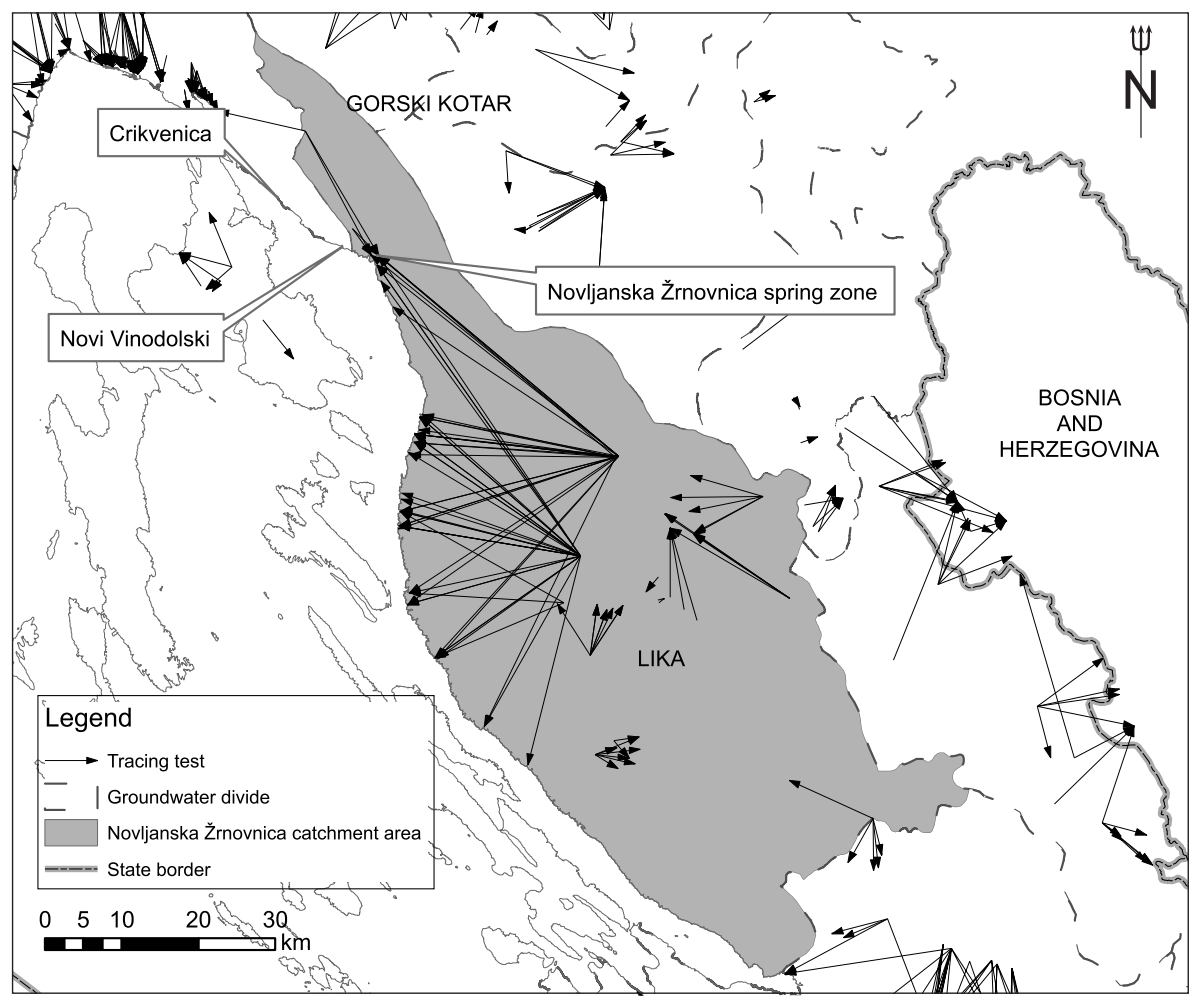

Fig. 3: The catchment of the spring zone Novljanska Žrnovnica and tracing test from the catchment (according to Biondić, B. et al. 2007b). tion of the main drainage direction of fresh water flow from the catchment towards the bay and in the same time the main direction of the seawater intrusion in the zone of spring during extreme dry periods (Fig. 4).

The spring zone Novljanska Žrnovnica is consisted of two groups of springs (Fig. 4), which function differently regarding to the influence of the seawater intrusions. The first group of springs, where the impact of the sea is not yet noticed, includes a permanent spring Čardak $\left(\mathrm{Q}_{\min }=110 \mathrm{l} / \mathrm{s}\right)$ and periodical spring Pećina $\left(\mathrm{Q}_{\max }=1.474 \mathrm{~m}^{3} / \mathrm{s}\right)$. Second group of springs, which is under periodic influence of the sea, consists of a permanent springs Stara Kaptaža $\left(\mathrm{Q}_{\min }=220 \mathrm{l} / \mathrm{s}\right)$ and Nova Kaptaža $\left(\mathrm{Q}_{\min }=80 \mathrm{l} / \mathrm{s}\right)$ and

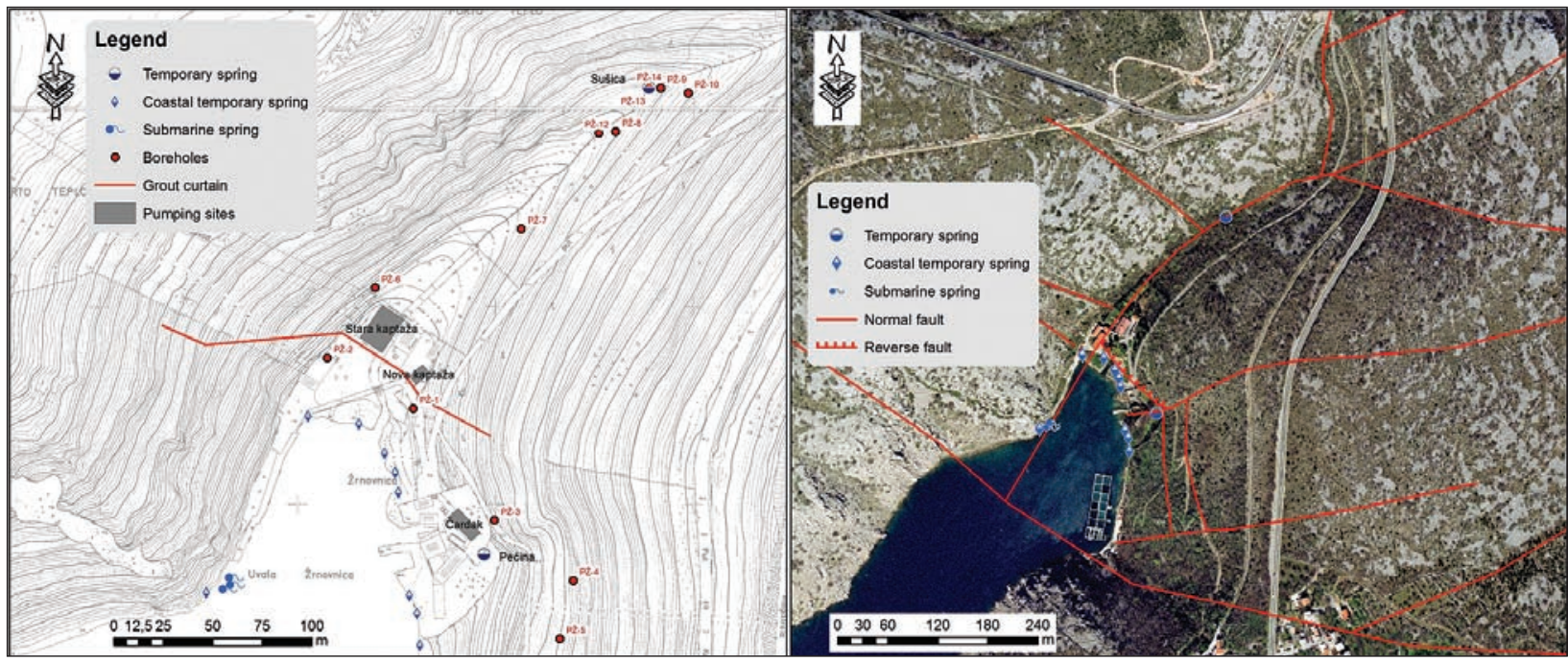

Fig. 4: Positions of the spring zone, grouting curtain, exploration boreholes, and main faults.

entirely built of layered well permeable limestones and limestone breccias of the lower Cretaceous age $\left(\mathrm{K}_{1}\right)$, which have been broken by strong cross-faults in several tectonic blocks. The most prominent fault extends along the bottom of the bay where the largest periodical and permanent springs are located, which are directly influenced by the sea. Faults in this spring zone have a func- periodical spring Sušica $\left(\mathrm{Q}_{\max }=2.723 \mathrm{~m}^{3} / \mathrm{s}\right)$. Springs Čardak and Pećina are hypsometrically about $2 \mathrm{~m}$ higher than springs Stara Kaptaža and Nova Kaptaža and therefore the influence of the sea is much lower. According to the results of measurements, the maximum amount of water on all captured springs, without the coastal and submarine springs, is about $7.5 \mathrm{~m}^{3} / \mathrm{s}$. 


\section{FRESHWATER-SALTWATER INTERFACE}

Occurrences of salinity on the spring zone Novljanska Žrnovnica were not recorded during each summer period, but the summer dry period of the year 2003 was one of the most extreme in the north Adriatic area. Already during the first part of the year was recorded an extremely low amount of rainfalls, about 30\% lower than average, and in late summer have been recorded absolute minimum of water levels in the north Adriatic rivers. Numerous coastal springs were under strong seawater intrusion influence (Bay of Bakar), and similar situation was reported on the spring zone Novljanska Žrnovnica (Fig. 5).

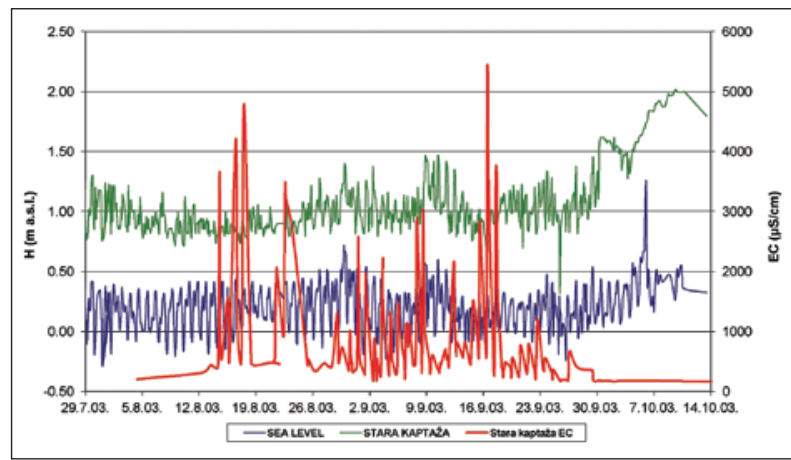

Fig. 5: Water level fluctuations, sea levels and electrical conductivity at spring Stara Kaptaža, during summer dry period 2003 (Biondić, B. et al. 2007a).

From Fig. 5 is evident that the entire system was under the direct influence of the sea dynamics (high and low tides) and the occurrences of salinity are associated with periods of lowest water level of fresh water on the spring Stara Kaptaža. The maximum value of the electrical conductivity (EC) reached a more than $5,000 \mu \mathrm{S} / \mathrm{cm}$, because of high chloride content. At the same time spring Čardak, situated in the other part of the spring zone, did not have elevated levels of electrical conductivity in spite of the position downstream of the previously executed grouting curtain. The direction of sea influence is linked to the propagation of a strong fault zone along the valley in the zone of spring Stara Kaptaža and periodical spring Sušica, while in the southern part of the bay there is a natural barrier, which results in higher water levels, and freshwater systems has significantly reduced the impact of seawater systems in relation to springs in the bottom of bay.

The spring zone Novljanska Žrnovnica is under permanent sanitary control because of the water-supply system. During the hydrogeological research were made the analysis of stable isotopes of oxygen and carbon (Fig. 6) on the springs Čardak and Stara Kaptaža to de- termine the origin of groundwater in the aquifer. Stable isotope analyses were made during the summer period (August 1999) with taking two samples per spring. Unfortunately, in that period temporary spring Sušica was completely dry and it was impossible to take samples on that spring. Fig. 6 shows the different origins of water on spring Čardak on the south side of the bay, and the spring Stara Kaptaža on the north side of the bay. At spring Stara Kaptaža groundwater flows direction are mainly related to the Gorski kotar region, situated in the north-western part of the catchment, and on the spring Čardak groundwater flows direction are related to Lika region, situated in the south-eastern part of the catchment. Isotope analyses shows differences in the dominantly recharge areas of that two springs. Lika region, the recharge area of Čardak spring, is located lower than Gorski kotar region, the recharge area of Stara Kaptaža spring. Water quality tests showed a high value, with all specific characteristics of karst aquifers. These are the extremely good water quality during summer dry periods, because at that time on the spring zone outflow waters that have the longest residence time. Slightly increased turbidity and the occurrences of bacterial pollutions are related to intensive rainy seasons. The quality of waters on the spring zone Novljanska Žrnovnica in all hydrological conditions fulfilled rigorous Croatian standards for drinking water quality (NN 47/08), with minimum water conditioning.

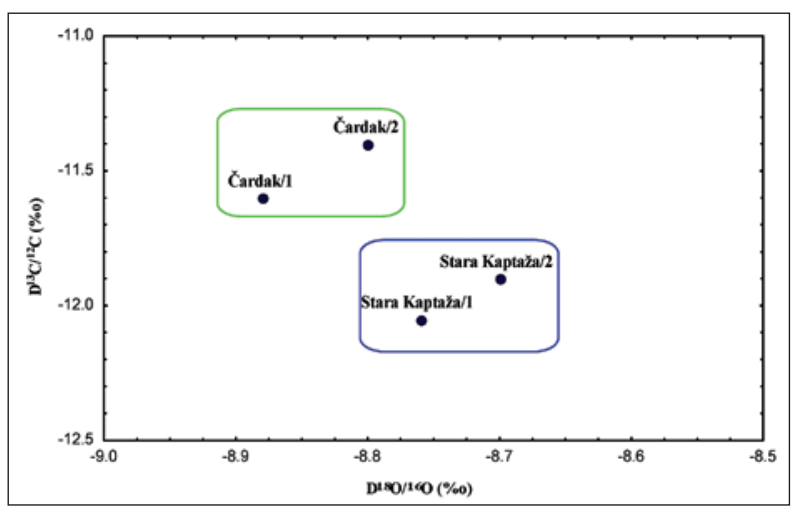

Fig. 6: Content ratio of stable isotopes of oxygen and carbon (Biondić, R. et al. 1999)

(1 - samples taken August $4^{\text {th }} 1999 ; 2$ - samples taken August $\left.19^{\text {th }} 1999\right)$.

According to the results of hydrogeological research the spring zone Novljanska Žrnovnica is possible to divide in two parts, which operate independently, what is reflected in a different relation to the influence of the sea and the different levels of fresh water in the discharge 
zone (spring Stara Kaptaža 0.217 m a.s.l.; spring Čardak $2.067 \mathrm{~m}$ a.s.1.). Hydrogeological conditions in the area of the spring zone had a direct impact on the further planning of detailed investigations in both parts of the source zone. In the area of the spring Cardak intention was to capture additional quantities of fresh water during summer dry periods, and in the northern part of bay to capture fresh water in the area outside of the sea water influences, as previously performed grouting curtain did not provide the minimum safety of exploitation of fresh water in extreme drought conditions.

The freshwater-saltwater interface during extreme drought conditions is a major problem for the most productive part of the spring zone Novljanska Žrnovnica. This problem is present in many coastal springs in the world, but nowadays the increasing exploitation of drinking water and the expected rise of sea levels due to global climate change, amplifies and increasing the problem of salinity of freshwater systems in coastal areas. Already in the late 19th and early 20th century, Ghyben (1889) and Herzberg (1901) separately analyzed and promoted the same principle of dynamic models of the freshwater-saltwater interface, which was later called Ghyben-Herzberg

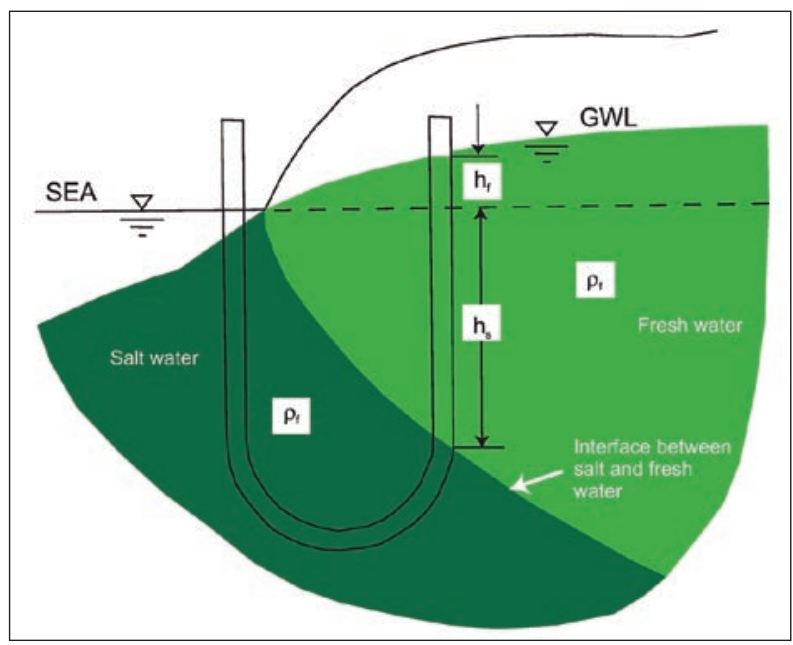

Fig. 7: Freshwater-saltwater interface according to Ghyben-Herzberg law (according to Bear \& Verruijt 1994).

law (Stringfield \& Legrand 1969, 1971). It is based on the difference in the density of freshwater $(\partial \mathrm{f})$ and saltwater

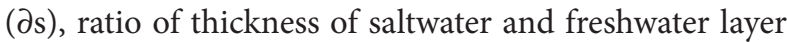
(HF) and the depth of occurrence of the mixing zone of freshwater and saltwater (HS) (Fig. 7).

According to Ghyben-Herzberg law the depth to the saltwater interface under hydrostatic conditions is about 40 times the height of the freshwater table above sea level (Ford \& Williams 2007). The Ghyben-Herzberg law has mainly developed for the steady state conditions in the sand island aquifers. In such conditions the consequences of pumping water into the coastal zones cause the thinning of freshwater layer and provide saltwater intrusion from the deep karst underground toward pump-

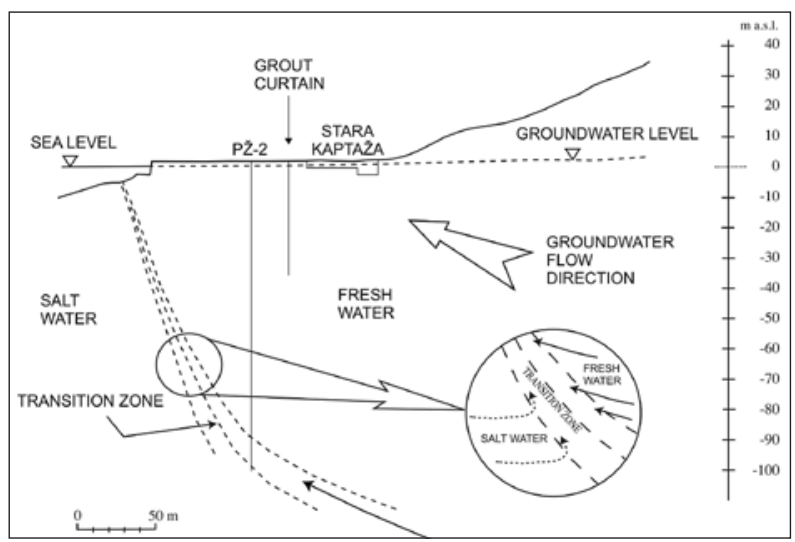

Fig. 8: Schematic representation of groundwater flow in the coastal aquifer Novljanska Žrnovnica (Biondić, B. \& Biondić, $R$. 2003).

ing facility. In the dynamic conditions of coastal karst springs, such as Novljanska Žrnovnica coastal aquifer, situation with the underground flow is much more complex, so Ghyben-Herzberg law may be used only as a rough approximation. Very interesting considerations has had Custodio (1985), which pays special attention to the dynamics of water in the mixing zone. According to him, there is a parallel upward flow of brackish water along the mixing zone, what the relations in the zone of sea influence make even more complex (Fig. 8). Gjurašin $(1942,1943)$ was also studying freshwater-saltwater interfaces on coastal and submarine springs. He related the salinity system on coastal springs and submarine springs with hydraulic ratio in tubes with different degrees of roughness.

\section{HYDROGEOLOGICAL INVESTIGATIONS}

These approaches and principles were of outmost importance for the interpretation of events at the spring zone
Novljanska Žrnovnica, and hydrogeological investigations were planned in accordance with the requirements 
of this approach. In the first phase of the study two deep exploration wells were drilled over $100 \mathrm{~m}$ below sea level in immediate coastal zone to determine the thickness of the freshwater lense over the mixing zone. Particularly interesting data were provided with exploration borehole PŽ-2 at the altitude of $1.78 \mathrm{~m}$ asl (Fig. 4), located in the zone of strong fault extended along the valley between the spring Stara Kaptaža and the sea. During the drilling to depths of $80 \mathrm{~m}$ below sea level the rock was low permeable and groundwater was completely fresh. After that, there was an eruption of water from the borehole. It was the upward pressure of groundwater from the mixing zone,

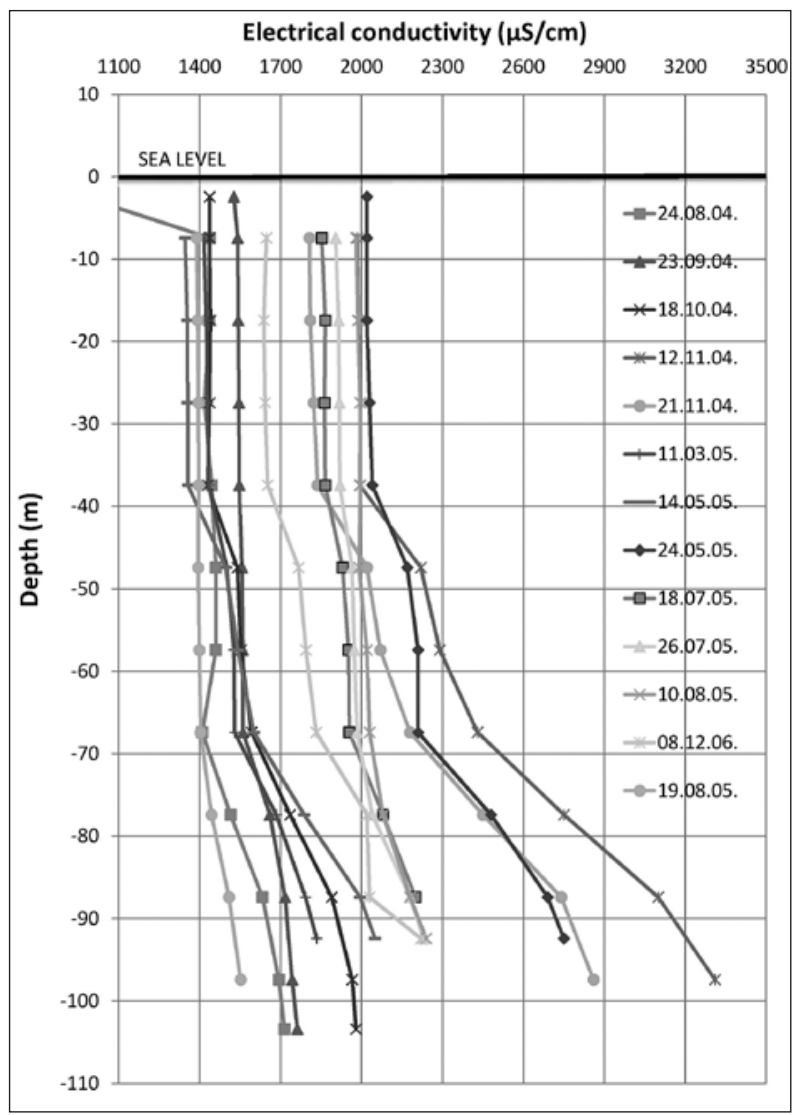

Fig. 9: Changes of electrical conductivity in the borehole PŽ-2.

as Custodio (1985) explained in his paper. Measurements of EC in exploration borehole have showed high values of EC in all hydrological conditions (1,300-3,300 $\mu \mathrm{S} /$ $\mathrm{cm}$ ) with a significant increase with depth (Fig. 9). High permeability and water salinity at depths greater than 80 $\mathrm{m}$ was also a good indicator of the inability of efficient separation of freshwater and marine systems with $40 \mathrm{~m}$ deep grouting curtain. This exploration borehole was a key argument for the cessation of thinking about the future planning and construction of expensive grouting curtain. It was necessary to change conceptual solutions of water sources rehabilitation by focusing on capturing freshwater in the hinterland, outside of the sea influence (Biondić, B. et al. 2005; Breznik \& Steinman 2008).

After that the investigations were focused to the hinterland of permanent spring Stara Kaptaža, to upstream periodic spring Sušica at the elevation of about $22 \mathrm{~m}$ a.s.l., where can be seen discharging of large water quantities during the rainy periods. The periodic spring Sušica is actually overflow for high waters of spring Stara Kaptaža. The maximum yield of periodic spring Sušica is $2.54 \mathrm{~m}^{3} / \mathrm{s}$, what is a good indicator of very karstified ascending pathways of groundwater from the zone of deep main drainage direction toward the permanent coastal spring zone. In dry periods, there is no water on spring Sušica, but it can be expected that the existing caverns are saturated with water at level equal to potential of permanent springs. Experiences from the earlier constructed water abstraction site in the city of Rijeka (Biondić, B. 1995) show that the pumping of groundwater from cavernous underground in zone of periodic spring Sušica can initiate upward groundwater flow from deep underground toward the abstraction site. On this way abstraction well in the zone of periodic spring Sušica, located about $250 \mathrm{~m}$ away from the seacoast and outside the zone of sea influence, can be used for the exploitation during the dry summer periods, when the permanent springs are brackish. For such conceptual abstraction model, except mentioned facts, there are many unknown facts, which should have been solved by additional research. These are primarily the depth and direction of groundwater flows between permanent and periodic springs, than changes in groundwater level in different hydrological conditions, changes in water temperature and EC according to the depth, etc.

The first step of additional research was the programme preparation of detailed geological and hydrogeological map with special attention to the positions of faults within water permeable carbonate rocks and the position of permanent and periodic springs and submarine springs. This was followed by making of two geophysical profile diagonal on the strike of the valley between periodic spring Sušica and permanent spring Stara Kaptaža. It was determined the strike of a strong fault zone along the valley and the zone of stronger karstification at depths up to $90 \mathrm{~m}$ below sea level, which was then used to determine the location of four exploration boreholes, $100 \mathrm{~m}$ deep in the profile between permanent and periodic spring (Fig. 10).

Measuring of groundwater levels in all hydrological conditions shows existing of hydraulic gradient from the zone of periodic spring Sušica toward the permanent spring Stara Kaptaža. In dry periods was on the exploratory borehole PŽ-9 in the zone of periodic spring mea- 
sured the water table at $4.15 \mathrm{~m}$ a.s.l., and in the same time on permanent spring Stara Kaptaža at 1.49 m a.s.l. Salinity of permanent spring occurs when the water level was lower than $1 \mathrm{~m}$ a.s.l. (Fig. 5) and then it is probably somewhat lower the water level in the zone of periodic
In dry periods, groundwater level retreats to the underground to levels of around $4 \mathrm{~m}$ a.s.l., and discharge from a large karst catchment area is related only to locations of permanent coastal springs and one submarine spring in the bay. In coastal areas during dry periods, mixing

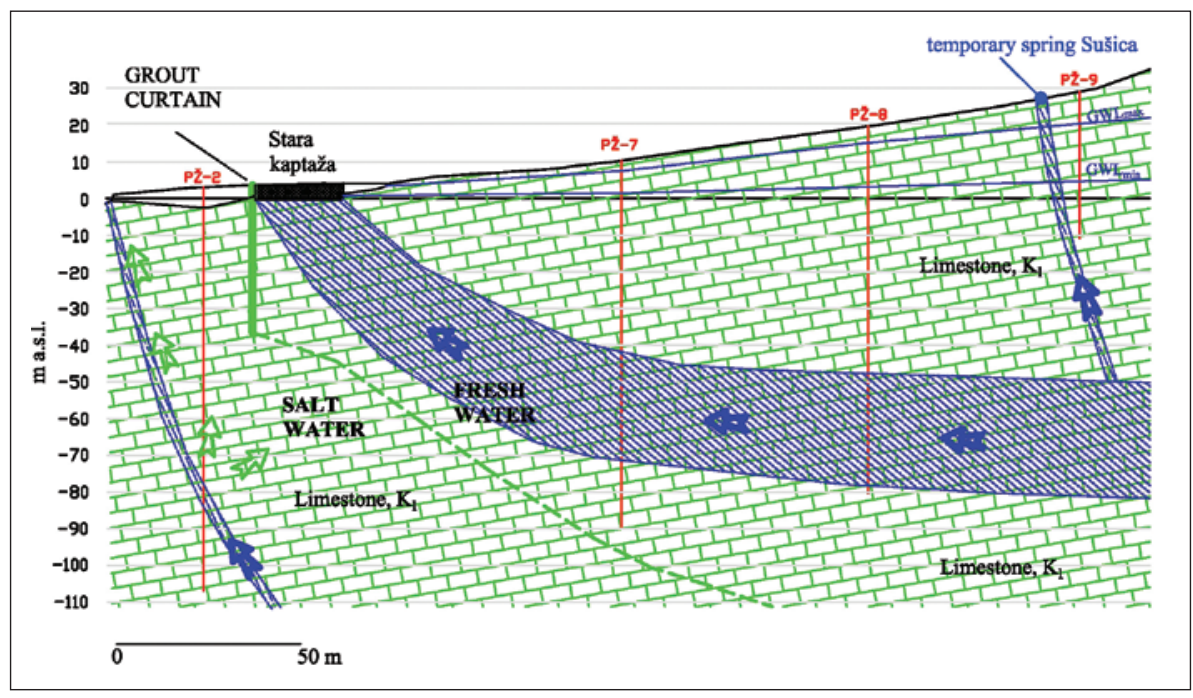

Fig. 10: Hydrogeological profile in the source zone of the spring Stara Kaptaža. zone of freshwater and saltwater slowly moves toward the aquifer land area, and cone-like zone is gradually approach permanent spring. Salinity of fresh spring water occurs at the time of overlapping negative elements in the zone of discharge: reduction of the gradient of freshwater from the catchment, large marine tides, and large extraction rate for water supply. Because of the increasing extraction rate during the summer period, due to growing tourism, salinity of water on a permanent spring Stara Kaptaža become more spring Sušica, too. The maximum value of EC at permanent spring, according to previously recorded values, increases over $5,000 \mu \mathrm{S} / \mathrm{cm}$ at the time of salinity, and spring water is then unusable for water supply. In hydrogeological profile (Fig. 10) between the permanent and periodic springs fluctuation of groundwater levels is evident in all hydrologic conditions. In the zone of periodic spring Sušica groundwater level is about $4 \mathrm{~m}$ a.s.l. during dry periods and during rainy season's groundwater under pressure flowing out.

According to Ghyben-Herzberg low four meters of freshwater layer at the location of periodic spring Sušica provides underground strike of freshwater systems to the depth of about $160 \mathrm{~m}$ b.s.l., which according to the results of derived hydrogeological investigations (geophysics, exploration drilling) include the main zones of groundwater flows toward the permanent spring in the coastal zone (Fig. 10) at depths around $70 \mathrm{~m}$ b.s.l. Measurements of EC with depth of exploration wells (Fig. 11) showed that it was exactly the freshwater system of uniform value of about $260 \mu \mathrm{S} / \mathrm{cm}$ in the range of permanent spring in the coastal area.

Hydrological measurements show that under conditions of high waters on the periodic spring Sušica discharge $2.8 \mathrm{~m}^{3} / \mathrm{s}$, which with regulated surface watercourse flows directly into the sea. Such large amounts of water on periodic spring are result of overflow of groundwater due to high pressure of freshwater from the catchment.

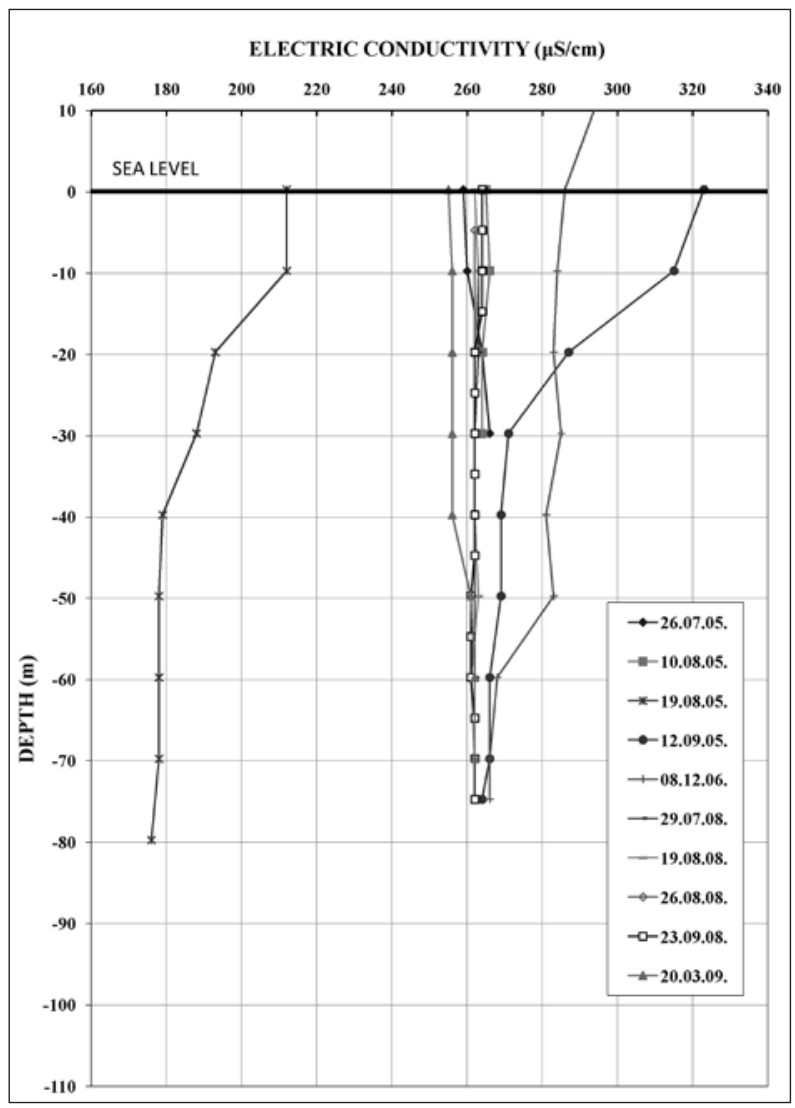

Fig. 11: Changes of electrical conductivity in the borehole PŽ-8. 
frequent and intense. In such conditions has been proposed the water capture in the zone of periodic spring Sušica, where is with water pumping possible to retarget groundwater flows from deep channels toward the pumps installed in a vertical object (drilled well), which cuts sub vertical cavern filled with groundwater.

The task of detailed research was to define the spatial position and depth of natural caverns, from which groundwater from deep underground emerges (overflow) on the surface in rainy periods. Cavern has irregular, vertical and sub vertical strike, partly filled with clay material, which can reduce the permeability of the underground and it is very difficult to determine the optimal position for the exploitation well. The optimal location was determined by geophysical investigations, exploration drilling with pumping test, and with groundwater tracing test. Geophysical investigations were conducted in a combination of methods of own potential, shallow seismic reflection and radar recording. The optimal position of the exploitation well was determined in the place of the most upstream part of the periodic spring Sušica with the open caverns at depths between 22 and $32 \mathrm{~m}$ below the ground surface, i.e. 0 to $12 \mathrm{~m}$ b.s.l., in the zone composed of highly fractured limestones, with caverns constantly saturated with groundwater. In the rainy periods, constructed exploration borehole has functioned as a one meter high water fountain (Fig. 12).

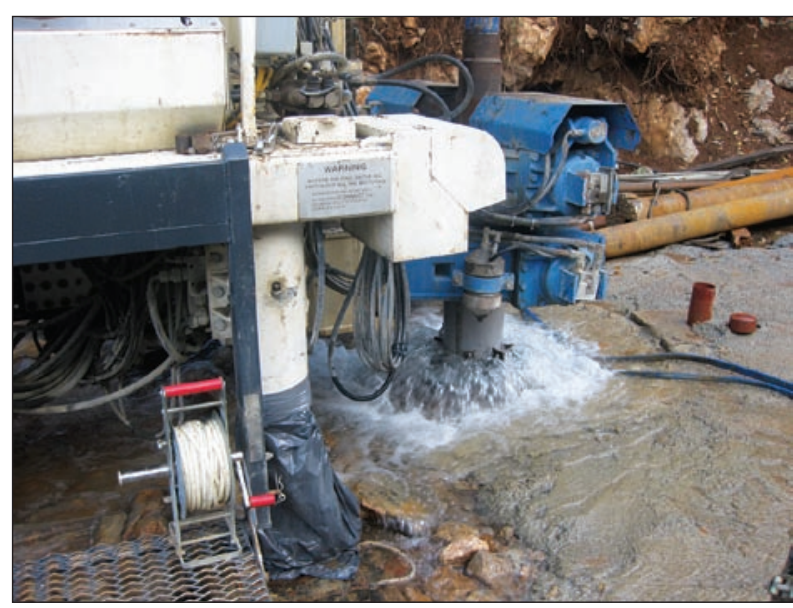

Fig. 12: "Water fountain" from the well at the location of occasional spring Sušica (Photo: H. Meaški).

In the period of cessation water overflow, borehole was examined with pump capacity of $5 \mathrm{l} / \mathrm{s}$ (Fig. 13). The initial groundwater level drawdown was about $6 \mathrm{~cm}$, and pumped water was after a short period very pure, which indicates the rapid establishment of relations with the deep karst aquifer drains toward the permanent coastal spring.
Tracing test of groundwater flows has been done from this borehole, which had to confirm the relation with permanent costal springs. In exploration borehole was injected $0.5 \mathrm{~kg}$ of $\mathrm{Na}$-fluorescein, with continuous water injection. Tracer in high concentration was registered after 4 hours on a permanent spring Stara Kaptaža. Most of the time it was necessary for tracer to reach the deep currents directed toward permanent coastal spring, through vertical cavern at the site of occasional spring Sušica. In this way, the groundwater connection of permanent and occasional spring was determined, and the ability for water capturing in the zone out of the sea influence.
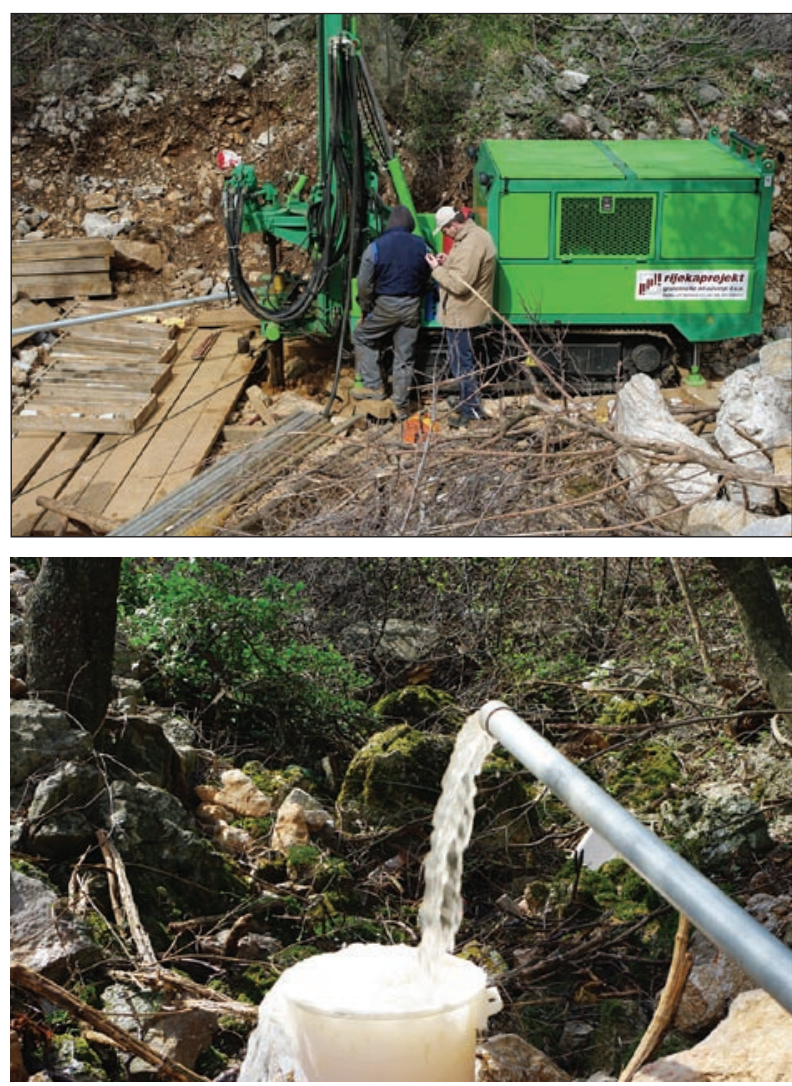

Fig. 13: Pumping test of the exploration well at the location of occasional spring Sušica (Photo: R. Biondić).

The exploitation well, $80 \mathrm{~m}$ deep, was located and constructed at the location of exploration borehole PŽ-13 (Fig. 4). Unfortunately, "step-pumping test" was made in conditions of high waters, and "continuouspumping test" in duration of 48 hours. The groundwater level at the beginning of the step-test was $0.20 \mathrm{~m}$ below the top of the opening column of the well. As compared to dry seasons, the difference is almost $16 \mathrm{~m}$, and the result of this pumping test should be taken with caution. The repeated pumping test should be carried out 
during the summer dry period. However, these tests showed good interaction of well with the deep groundwater flows through a karst aquifer toward permanent springs Stara Kaptaža and Nova Kaptaža. The step-test was carried with quantities of 20,30, 40 and $47 \mathrm{l} / \mathrm{s}$, and total duration of extraction with different capacities was 3 hours (Fig. 14).

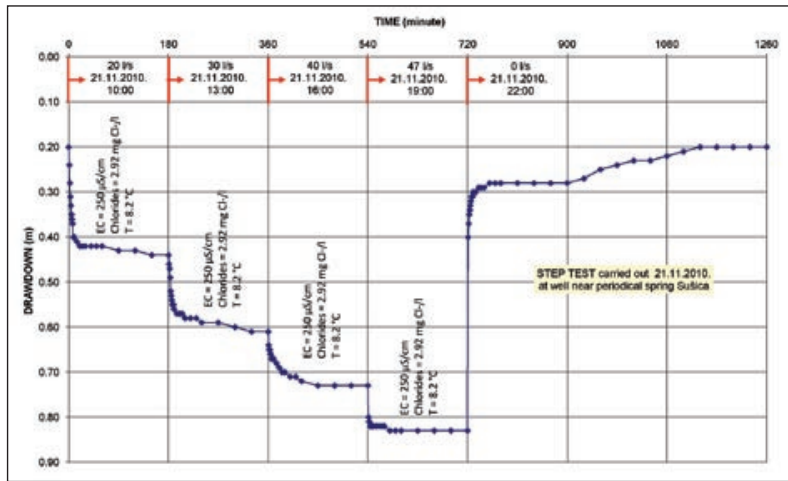

Fig. 14: The reduction curve obtained by the step-test and return levels after cessation of pumping.

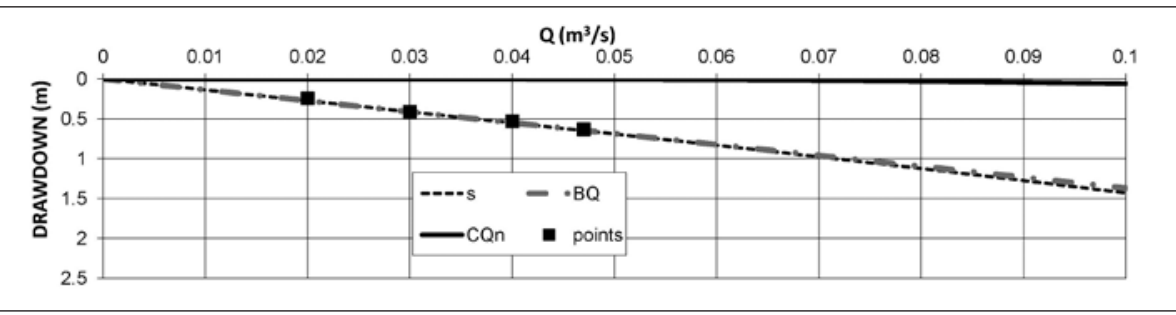

Fig. 15: Diagram s/f(Q) - prognose of posible quanities.

A relatively rapid drawdown in each of used capacity occurred by switching on the pump, because the lowering of groundwater in the well had to "cause" water flows from the deep underground. Total drawdown during step-test was $0.56 \mathrm{~m}$. With cessation of pumping in the first minute return of $0.40 \mathrm{~m}$ was recorded, and complete recovery of groundwater level was after few hours. Throughout the step-test electric conductivity, temperature and chloride concentration of the pumped water were not changed. EC of pumped water was $250 \mu \mathrm{S} / \mathrm{cm}$, temperature $8.2^{\circ} \mathrm{C}$, and the chloride concentration 2.92 $\mathrm{mg} \mathrm{Cl} / 1$ during the all four steps. All this indicated very satisfactory first results for future development of exploitation site for dry periods.

Diagram $s / f(Q)$ (Fig. 15) provides forecasts of water quantities, which can be drawn from a finished well. In hydrological conditions of high waters, these are not realistic indicators, but present the possibility of well behaviour in conditions of summer dry periods, as water flows from deep underground toward pumping sites will go through the same underground channels. With extraction rate of about $50 \mathrm{l} / \mathrm{s}$, according to the curve water level drawdown is about $0.6 \mathrm{~m}$, while increasing extraction rates to $100 \mathrm{l} / \mathrm{s}$ can caused drawdown of about $1.5 \mathrm{~m}$.

In the final phase of the pumping test, water samples were taken for the chemical analysis, which determines the value in accordance with the Regulations on the safety of drinking water in Croatia (NN 47/2008). All parameters were below the allowable values for drinking water (MAC), except turbidity (5.58 NTU units) and microbiological content.

\section{FINAL CONSIDERATIONS}

The spring zone Novljanska Žrnovnica is a typically coastal spring opened to the sea influence that drained karst catchment of enormous dimensions. In rainy periods the spring zone outflow is about $8 \mathrm{~m}^{3} / \mathrm{s}$, while in dry summer periods, these outflow is reduced to a few hundred litres per second. The spring zone is partly captured for water supply of towns Novi Vinodolski, Crikvenica and surrounding municipalities. This is a typical tourist area and the highest consumption of drinking water is in time when spring discharge is the lowest. Steady growth of tourism had a consequence of the permanent increase of exploitation. For the illustration can be mentioned that at the time of the first capture of the spring zone (1932) was exploited just about $30 \mathrm{l} / \mathrm{s}$, and today during the tourist season exploitation rises to $250 \mathrm{l} / \mathrm{s}$. With increasing exploitation of water during summer dry periods the spring zone has been brought in limited conditions of the freshwater-saltwater interface, especially on the water richest part of the spring zone, the spring Stara Kaptaža. The occasional freshwater salinity, at the time of greatest consumption, has opened the need for rehabilitation of the spring zone, since occasional salinity can cause huge economic damage. Previous attempts of rehabilitation of the endangered part of spring zone by separation of 
freshwater system from the sea influence with the $40 \mathrm{~m}$ deep grouting curtain, did not give satisfactory results, because the grouting curtains were obviously too shallow, compared to the depth of karstification of carbonate rocks in the coastal area. Further deepening of the grouting curtain would be technically and financially very demanding project, with uncertain final outcomes. Based on additional hydrogeological researches the concept of rehabilitation of the spring zone Novljanska Žrnovnica has been changed and capturing of freshwater in the immediate catchment area outside of the sea influence was proposed.

Hydrogeological investigations have shown that the zone of permanent discharge of spring Stara Kaptaža and periodic spring Sušica, approximately $250 \mathrm{~m}$ far from the shore, are parts of the same groundwater inflow from the large karst catchment. The main groundwater conduits are at the depth of about $80 \mathrm{~m}$ b.s.l., with the effect of upwards groundwater flows toward places of permanent and periodic springs. Measurements of groundwater levels on exploratory boreholes have shown the existence of a hydraulic gradient from periodic toward the permanent coastal springs. The minimum measured groundwater level in the zone of periodic spring Sušica is approximately $4 \mathrm{~m}$ a.s.l. and according to Ghyben-Herzberg law indicates deep spreading of freshwater systems to about $160 \mathrm{~m}$ b.s.l. Regarding to the depth of karstification of a maximum $150 \mathrm{~m}$ b.s.l. it can be concluded that on the site of periodic spring the whole groundwater system is freshwater and the mixing zone is kept in the zone of the permanent spring. The salinity of permanent spring occurs during increased exploitation of the freshwater, and the consequence is the slow moving, uplifting, and forming of the cone-mixing zone of freshwater and saltwater toward the permanent spring.

Investigations have highlighted the value of the capturing freshwater from the karst underground in the zone of periodic spring Sušica, especially for the conditions of extreme dry periods. Based on the hydrogeological results, $80 \mathrm{~m}$ deep exploitation well was carried out at the site of periodic spring, from where is possible by groundwater pumping to redirect groundwater flows from the deep drains toward pumping facility. Estimated pumping rate is $60 \mathrm{l} / \mathrm{s}$, because that quantity of freshwater, together with existing permanent springs, which do not become salty, is adequate for the present water supply needs. Water quality on constructed well is after long-term pumping same as on the natural permanent springs.

\section{REFERENCES}

Bear, J. \& A. Verruijt, 1994: Modeling groundwater flow and pollution. Theory and applications of transport in porous media.- Reidel Publishing Company, pp 414, Dordrecht, The Netherlands.

Biondić, B. \& B. Šaban, 1973: Novljanska Žrnovnica 1972 - Hydrogeological researches (Novljanska Žrnovnica 1972 - Hidrogeološki radovi).- Unpublished technical report, Croatian Geological Survey, Zagreb.

Biondić, B. \& V. Goatti, 1973: Tracing test of Ličanka River ponor in Lič polje near Fužine (Bojenje ponora Ličanke u Lič polju kod Fužina).- Unpublished technical report, Croatian Geological Survey, Zagreb.

Biondić, B. \& V. Goatti, 1975: Tracing test of Gacka River ponor near Otočac (Bojenje ponora Gacke kod Otočca. HG radovi).- Unpublished technical report, Croatian Geological Survey, Zagreb.
Biondić, B., 1995: Stop D-1: The spring Zvir and abstraction structure Zvir II (Postaja D-1: Izvor Zvir i kaptažni zahvat Zvir II).- In: Vlahović, I. \& Velić, I. (eds.) Excursion guide-book. First Croatian geological congress (Vodič ekskurzija 1. Hrvatski geološki kongres). pp 141-148, Croatian Geological Survey (Institut za geološka istraživanja), Zagreb.

Biondić, B., Brkić, Ž., Biondić, R. \& D. Singer, 1996: Water management base of the Republic of Croatia. Hydrogeology, I. phase (Vodnodgospodarska osnova Republike Hrvatske. Hidrogeologija. I. faza).- Unpublished technical report, Croatian Geological Survey, Zagreb.

Biondić, B. \& R. Biondić, 2003: State of seawater intrusion of the Croatian coast.- In: Lopez-Geta, J.A., De Dios Gomez, J. \& De La Orden, J. (eds.). Coastal aquifers intrusion technology: Mediterranean countries. Instituto Geologico y Minero de Espana (IGME, Geological Survey), pp 225-238, Madrid. 
Biondić, B., Biondić, R. \& S. Kapelj, 2005: The sea water influence on karstic aquifers in Croatia.- In: Tulipano, L. (ed.). COST Environment 621 Action: Groundwater management of coastal karstic aquifers. Final report. Office for Official Publications of the European Communities, pp 303-311, Luxembourg.

Biondić, B., Biondić, R. \& H. Meaški, 2007: Water supply pumping site Novljanska Žrnovnica. Hydrogeological investigations for new capture for water supply (Crpilište Novljanska Žrnovnica. Hidrogeološki istražni radovi za novi kaptažni zahvat).- Unpublished technical report, GEO INFO, Zagreb.

Biondić, B., Biondić, R. \& H. Meaški, 2007: Example of problem solving of the salinity increase of the karst aquifers in Croatia.- In: Pulido Bosch, A., LopezGeta, J.A. \& G. Ramos Gonzalez, (Eds.). Los acuiferos costeros: Retos y soluciones (Coastal aquifers: challenges and solutions). Instituto geologico $\mathrm{y}$ minero de Espana (IGME), pp 927-938, Madrid.

Biondić, B., Biondić, R. \& H. Meaški, 2009: Detail hydrogeological investigations on the water supply site Novljanska Žrnovnica for the constructing of additional capture on the location of the Sušica. Final report. (Detaljni hidrogeološki istražni radovi na izvorištu Novljanska Žrnovnica za izgradnju dodatnog crpilišta pitke vode na lokaciji Sušica. Završno izvješće).- Unpublished technical report, GEO INFO, Zagreb.

Biondić, B. \& R. Biondić, 2010: Hydrogeological investigations for the drilling of exploitatory well near the temporary spring Sušica on the Novljanska Žrnovnica water-supply site. (Hidrogeološki istražni radovi za potrebe izgradnje zdenca kod povremenog izvora Sušica na crpilištu Novljanska Žrnovnica).- Unpublished technical report, GEO INFO, Zagreb.

Biondić, R., 2004: Selected Coastal Karst Aquifers (Croatia): Martinšćica, Periolo, Novljanska Žrnovnica, Jurjevska Žrnovnica.- In: Calafora, J.M. (ed.). The main coastal karstic aquifers of southern Europe: a contribution by members of the COST-621 Action 'Groundwater management of coastal karstic aquifers' (EUR 20911). Office for Official Publications of the Euroepan Commities, pp 33-36, Luxembourg.

Biondić, R., Biondić, B. \& S. Kapelj, 1999: Novljanska Žrnovnica spring. Hydrogeological researches (Izvorište Novljanska Žrnovnica. Hidrogeološka istraživanja).- Unpublished technical report, Croatian Geological Survey, Zagreb.
Breznik, M. \& F. Steinman, 2008: Hydromechanism and desalinization of coastal karst aquifers: Theory and cases.- Acta Carsologica. 37, 2-3: 197-212.

Custodio, E., 1985: Saline intrusion.- Hydrogeology in the service of man. Memories of the 18th Congress of the IAH, p 65-90, Cambridge, UK.

Ford, D. \& P. Williams, 2007: Karst Hydrogeology and Geomorphology.- John Wiley \& Sons. pp 562.

Gjurašin, K., 1942: Contribution of the coastal karst hydrography (Prilog hidrografiji primorskog krša).Tehnički vjestnik. Glasilo Hrvatskog društva inženjera, 59, 4-6, 107-112.

Gjurašin, K., 1943: Contribution to the karst hydrography (Prilog hidrografiji krša).- Tehnički vjestnik. Glasilo Hrvatskog društva inženjera, 60, 1-2, 1-17.

Grimani, I., Šušnjar, M., Bukovac, J., Milan, A., Nikler, L., Crnolatac, I., Šikić, D. \& I. Blašković,1963: Basic geological map S 1:100.000. Guidebook. Sheet Crikvenica (Tumač osnovne geološke karte M 1:100.000. List Crikvenica). Savezni geološki zavod, Beograd.

Narodne novine 47/08, 2008: Regulation on health regularity of water for public water-supply. (Pravilnik o zdravstvenoj ispravnosti vode za piće). Zagreb.

Pavlin, B., 1973: Žrnovnica spring. Zone of Stara kaptaža spring. Protection against the loss of spring water and salinization from sea (Izvorište Žrnovnica. Uplivno područje Stare kaptaže. Zaštita protiv gubitka izvorske vode i zaslanjujućeg upliva mora. Idejni projekt).Unpublished technical report, Elektroprojekt, Zagreb.

Stringfield, V.T. \& H.E. Legrand, 1969: Hydrology of carbonate rock terranes $-A$ review with special reference to the United States.- Journal of Hydrology, 8, 349-417.

Stringfield, V.T. \& H.E. Legrand, 1971: Effects of karst features on circulation of water in carbonate rocks in coastal areas.- Journal of Hydrology, 14, 139-157.

Šegota, T., 1968: Sea level in Holocen and younger part of Würm (Morska razina u holocenu $i$ mladem dijelu würma).- Geografski glasnik, broj 30, Geografsko društvo hrvatske i Sveučilište u Zagrebu, pp. 15-39, Zagreb.

Šušnjar, M., Bukovac, J., Nikler, L., Crnolatac, A., Milan, A., Šikić, D., Grimani, I., Vulić, Ž. \& I. Blašković, 1970: Basic geological map S 1:100.000. Sheet Crikvenica L-33-102 (Osnovna geološka karta M 1:100.000. List Crikvenica L-33-102).- Savezni geološki zavod, Beograd. 